Исследование также показало насушную необходимость изучения норм конституций и других законодательньх актов субъектов зарубежньх федераций с целью использования богатейшего правового опьта развитых стран мира при совершенствовании законодательства субъектов Российской Федерации.

1. Constitution of the State of California./The Constitution of the United States of America and the Constitution of the State of California. Sacramento, 1996, p. 79-222; Конституция штата Илинойс. - В сб.: Соединенные Штаты Америки: Конституция и законодательные акты: Пер. с англ. - М., 1993, с. 98-137.

2. См.: Jbid. The Constitution..., p. 95-96.

3. См.: Jbid. The Constituiton..., p. 123; Соединенные Штаты..., с. 119; Конституция Штата Аляска/Изд-е Нац. Дем. Ин-та Междун. Отн-й. М., 1995, с. $18-19$.

4. См.: Конституция Массачусетса. - В сб.: Соединенные Штаты Америки: Конситуция и законодатељьые акты: Пер. с англ. М., 1993, с. 50-97.

5. См.: Ubid. The Constituiton..., p. 123.

\title{
ПРАВОВЫЕ ВОПРОСЫ ВЗЯТИЯ ЛИЦА ПОД СТРАЖУ ДЛЯ ОБЕСПЕЧЕНИЯ ВЫДАЧИ
}

\section{П. Н. Б и р ю к о $\mathbf{B}^{*}$}

Как известно, в настоящее время в РФ отмечается значительный рост преступности, в том числе с "иностраинным" элементом: существенно выросло количество преступлений, совершаемы иностранцами; лица, совершившие преступление в РФ, часто скрываются за рубежом и наоборот.

Российское государств активно сотрудничает в борьбе с преступностью: заключает соглашения о пресечении и наказании за международные преступные деяния, взаимодействует с мехдународными правоохранительными организациями, оказывает правовую помощь по уголовньм делам.

Одним из видов правовой помоџи по уголовным делам является взятие лица под страху для обеспечения выдачи.

В международном праве различают два вида взятия под стражу в целях выдачи: для привлечения к утоловной ответственности и для исполнения приговора. Правовое регулирование этих действий несколько отличается друг от друга.

- Доцент Воронежского Государственного университета, кандидат кридичесkrx нayk. 
Российская Федерация является участником нескольких десятков международньх договоров, предусматривающих возможность взятия лища под стражу в целях выдачи. Эти договоры условно можно разделить на четыре групाы:

межтосударственные соглашения о борьбе с отдельными видами преступлений;

межгосударственные договоры о правовой помощи по уголсвным делам;

соглашения, заключаемые Генеральной прокуратурой РФ;

межведомственные соглашения МВД РФ, ФСБ РФ.

Рассмотрим их подробнее.

1. В межтосударственньх соглашениях о борьбе с отдельньми видами преступлений (см. 5 Конвенции о борьбе с незаконным захватом воздушньх судов 1970 г., ст. 6 Конвенции о борьбе с захватом заложников 1979 г., ст. 6 Конвенции ООН о борьбе против незаконного оборота наркотических средств и психотропньх вешеств 1988 г. и т.д.) предусматривается возможность задержания лица с целью его вьдачи.

Убедившись, что обстоятельства того требуют, государство, на территории которого находится преступник, заключает его под стражу. При этом лицу, заключенному под стражу, оказывается содействие в установлении контактов с блихайшим представителем государства его гражданства (ст. 6 Конвенции о борьбе с незаконными действиями, направленными против безопасности гражданской авиации, 1971 г.) и посещения его представителем этого государства (ст. 7 Конвенции о борьбе с незаконньми актами, направленньми против безопасности морского судоходства, 1988 г.).

В то же время самого порядка заключения под стражу конвенции не регламентирукт, относя этот вопрос к сфере действия национального утоловно-процессуального законодательства.

2. Межтосударственные договоры о правовой помоши предусматривают оба вида заключения под стражу: для привлечения к ответственности и исполнения приговора. Эти договора устанавливают условия, при которых производится заключение под стражу, определяют реквизиты документов, необходимьх для принятия решения об аресте лица, сроки задержания, порядок освобождения лица из под стражи и т.д.

Например, согласно ст. 60 Конвенции СНГ по правовой помоши и правовьм отношениям по грахданским, семейньп и уголовным делам 1993 г., по получении требования о выдаче запрашиваемое государство немедленно принимает меры к взятию под стражу лица, выдача которого требуется, за исключением тех случаев, когда выдача не может быть произведена. ${ }^{1}$ 
В 1997 г. страны СНГ приняли “Протокол к Конвенции о правовой помощи и правовьх отношениях по грахдансктм, семейным и уголовным делам от 22 января 1993 года (Протокол Россией не ратифицирован и в силу пока не вступил).

Протокол предполагает изложить ст. 60 Конвенции в следуюшей редакции: "по получении требования о выдаче запрашиваемая Договаривающаяся Сторона немедленно принимает меры к розыску и взятию под стражу лица, выдача которого не может быть произведена". Предлагается также дополнить Конвенцию статьей 61 (2), по которой время содержания под стражей лица, взятого под стражу, в случае его выцачи, засчитывается в обший срок содержания под стражей, предусмотренный законодательством страны, которой это лицо выдано. Как видим, изменения Конвенции не затрагивакот существа вопроса в отношений взятия лица под стражу.

Нормы, аналогичные зафихсированньм Конвенцией СНГ 1993 г., закреплены в большинстве двусторонних договоров о правовой помощи (см., например, ст. 43 Договора между СССР и Республикой Кипр о правовой помощи по грахданским и уголовным делам 1984 r. $^{3}$, ст. 68 Договора мехду РФ и Республикой Албания о правовой помощи и правовых отношениях по грахданским, семейным и уголовным делам $1995 \mathrm{r.}^{4}$, ст. 68 Договора между РФ и Республикой Грузия о правовой помощи и правовых отношениях по грахданским, семейным и уголовным делам 1995 г. $^{5}$ и др.),

К просьбе о выдаче для осуществления утоловного преследования должна быть приложена заверенная копия постановления о взятии лица под стражу с описанием деяния, составляющего преступление, $\mathrm{k}$ просьбе о выдаче для исполнения приговора - заверенная копия приговора (ст. 67 Договора между РФ и Эстонской Республикой о правовой помощи и правовых отношениях по гражданским, семейным и уголовным делам $1995 \mathrm{r}^{6}$ и др.).

При этом запрашиваемое государство может затребовать дополнительные сведения, если просьба о выдаче не содержит всех указанньг в договоре необходимьх данньх (ст. 69 Договора между РФ и Литовской Республикой по правовой помоши по гражданским, семейным и уголовным делам 1992 г.7, ст. 69 Договора между РФ и Латвийской Республикой о правовой помощи по грахданским, семейным и уголовным делам $1993 r^{8}{ }^{8}$ и др.). Запрашиваюшая сторона долхна ответить на эту просьбу в срок, не превьпшащий одного месяца; этот срок может быть продлен (как, правило, на 15 дней) при наличии уважительньх причин. Если запрашивающая сторона не представит в установ- 
ленный срок дополнительньх сведений, запрашиваемое государство может освободить лицо, взятое под стражу.

Таким образом, речь в договорах о правовой помощи идет о применении меры пресечения в виде заключения под стражу.

Как известно, действующий УПК РСФСР не содержит специальньх правил о взятии лица под страху для обеспечения выдачи. Данное процессуальное действие осушествляется в РФ в обшем порядке (ст. ст. 11, 96, 91.1 УПК). На основании "международного следственного поручения" в РФ выносится постановление о заключении лица под стражу. При этом УПК не предусматривается права арестованного на контакт с представителем государства своего гражданства и права посешения его этим государством.

Следует учитьвать, что в соответствии со ст. 96 УПК заключение под страху в качестве меры пресечения применяется по делам о преступлениях, за которые законом предусмотрено наказание в виде лишения свободы на срок свыше одното годая Однако в исключительньх случаях эта мере пресечения может быть применена по делам о преступлениях, за которые законом предусмотрено наказание в виде лишения свободы и на срок не свыше одного года.

Вместе с тем не всякое запрашиваемое иностранным государством к выдаче лицо может быть арестовано. Так, в РФ не выдаются (a, следовательно, и не могут быть заключены под стражу с целью вьдачи) граждане РФ, лища, в отношении которьх на территории РФ за то же преступление был вынесен приговор или постановление о прекращении производства по делу, вступившее в законную силу. Не является также основанием для выдачи совершение лицом преступления, за которое предусматривается наказание менее одного года лишения свободы или иное боле мягкое наказание. Очевидно, что в таких случаях заключение под стражу применяться не может.

Кроме того, необходимо принимать во внимание, что на основании некоторых договоров о правовой помощи лицо может быть взято под стражу и до получения требования о выдаче по так называемому "ходатайству" (ст. 61 Конвенции СНГ 1993 г.,

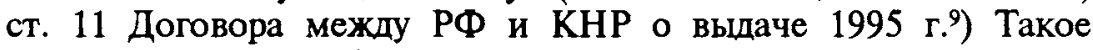
ходатайство может быть передано по почте, телеграфу, телексу или телефаксу. В ходатайстве должны содержаться сведения о лице, выдача которого требуется, о его местожительстве и местопребьвании, если об этом известно; краткое описание фактических обстоятельств дела; сведения о наличии постановления о взятии под страху или ордера на арест либо вступившего в 
законную силу приговора и указание на то. что просьба о выдаче будет выслана незамедлительно.

Срок содержания под стражей для таких лиц - один месяц. Если требование о его выдаче не поступит в течение одного месяца со дня взятия под стражу, лицо должно быть освобождено (ст. 62 Конвенции СНГ 1993 г.). Данный срок может быть продлен на 10 дней, если до его истечения от запрашивающего государства поступит соответствующее мотивированное ходатайство (ст. 11 Договора между РФ и КНР о выдаче 1995 г.).

По законодательству РФ (ст. 97 УПК) содержание под стражей при расследовании преступлений по уголовным делам не может продолжаться более двух месяцев (этот срок может быть продлен прокурорами различных уровней). Как видим, возможна коллизия международной и внутригосударственной норм. Такую коллизию нужно решить по правилу: если международным договором установлены иные правила. чем законом, действуют правила международного договора (ч. 4 ст. 15 Конституции РФ).

Интересно также отметить, что в соответствии с договорами о правовой помощи лицо может быть задержано и без ходатайства, если имеются предусмотренные законодательством основания подозревать, что оно совершило на территории другого государства преступление, влекущее выдачу (ст. 70 Договора между РФ и Азербайджанской Республикой о правовой помощи и правовых отношениях по грахданским, семейным и уголовным делам 1992 г. $^{10}$, ст. 70 Договора между РФ и Латвийской Республикой о правовой помощи и правовых отношениях по гражданским, семейным и уголовным делам 1993 г. и т.д.). Задержанное лицо должно быть освобождено, если требование о его выдаче не поступит в течение срока, предусмотренного законодательством для задержания (ст. 62 Конвенции СНГ 1993 г.).

В данном случае применительно к Российской Федерации речь идет о задерхании в порядке ст. 122 УПК. Однако ст. 122 содержит четкий перечень (“только при наличии”) оснований для задержания. В этом перечне "международные" основания для задержания отсутствуют. Поэтому на территории РФ лицо, подозреваемое в совершении преступления за рубежом, может быть задержано лишь в том случае, если оно покушалось на побег или не имеет постоянного места жительства, или когда не установлена личность подозреваемого.

О взятии лица под стражу или о задержании необходимо немедленно уведомить запрашиваюшее государство (ст. 45 Договора между СССР и Республикой Кипр о правовой помощи по 
гражданским и уголовным делам 1984 г., ст. 70 Діоговора между РФ и Республикой Молдова о правовой помоши и правовьх отношениях по гражданским, семейным и уголовным делам 1993 г. $\left.^{11}\right)$. Аналогичное положение целесообразно бы внести и в российский УПК.

3. По соглашениям Генеральной прокуратуры РФ сотрудники российской прокуратуры обязаны оказывать правовую помошь по выполнению отдельных процессуальных действий, в т. ч. и заключение под стражу (ст. 2 Соглашения правовой помощи и сотрудничества между органами прокуратуры 1992 r. $^{12}$, ст. 1 Соглашения С прокуратурой Республики Армения 1993 г., ст. 1.1 Соглашения с Генеральной прокуратурой Республики УКраина 1993 г.). При этом выдача (и, соответственно, заключение под стражу) лиц, совершивших преступление на территории государства-участника, допускается только в соответствии с действующим законодательством и межтосударственными соглашениями (ст. 5 Соглашения с Прокуратурой Республики Грузия 1993 г., ст. 9 Соглашения с Прокуратурой Республики Молдова 1993 г.).

“Выполнение отдельньх процессуальньх действий” в порядке правовой помоши, предусмотрено и Указанием Генерального прокурора РФ “О порядке выполнения ходатайств о правовой помощи” 1992 г. в ред. 1993 г.). Нормы Указания о юридических основаниях правовой помощи, о порядке взаимодействия органов прокуратуры с зарубежньми органами юстиции, о сроках выполнения ходатайства и т.д. в принципе не отличаются от предусмотренных международными соглашениями.

4. Межведомственные соглашения МВД РФ и ФСБ РФ.

Нужно казать, что далеко не все ведомственные договоры предусматривают возможность задержания или ареста подлежащих выдаче лиц. Такие нормы отсутствуют, в частности, в Соглашении о сотрудничестве между МВД РФ и МВД Республики Болгария 1993 г., Меморандуме о взаимопонимании меду МВД РФ и Королевской конной полицией Канады 1993 г., Соглашении мехду МВД РФ и МВД Итальянской Республики о борьбе с незаконным оборотом наркотических средств и психотропньх веществ 1993 г. и ряде других договоров.

Те соглашения, в которьх имеются нормы об аресте лиц с целњю выдачи (ст. 8 Соглашения между МВД РФ и МВД Украины 1992 г., ст. 4 Соглашения между МВД РФ и МВД Республики Молдова 1993 г.), закрепляют лишь общее правило: на основании международного договора стороны оказывают друг другу содействие в задержании лиц и заключении их под стражу. Порядок 
этих действий определяется национальным законодательством и межтосударственными договорами.

В то же время в нормативньх актах МВД РФ достаточно подробно регламентируются вопросы задержания и ареста в целях последующей выдачи. В числе этих актов можно назвать инструкцию об оперативно-розыскной деятельности, указание 1-го зам. Министра внутренних дел РФ "О задержании по поручениям правоохранительньх органов зарубежньх государств лиц, совершивших преступление” 1996 г. и др. документы.

При решении вопроса о заключении под стражу запрашиваемого к выцаче лица органам внутренних дел следует учитывать, что применение меры пресечения и по международным договорам РФ, и по законодательству возможно лишь при отсутствии у этого лица российского гражданства. Поэтому поручать органам внутренних дел розыск и арест запрашиваемых лиц можно только после проверки их гражданской принадлежности. Вывод о наличии или отсутствии у лица грахданства РФ оформляется в виде заключения паспортно-визовой службы.

O каждом случае задержания запрашиваемых к выдаче иностранцев необходимо уведомлять Генеральную прокуратуру РФ, ГУУР МВД РФ, НЦБ Интерпола в РФ, надзирающего прокурора и учреждение юстиции запрашивающего государства.

Необходимо также помнить, что лицо, взятое под стражу в соответствии с поручением Генеральой прокуратуры РФ, мохет быть освобождение лишь по указанию Генеральной прокуратуры.

Таковы, в общих чертах, положения о взятии под стражу для обеспечения выдачи, предусматриваемые договорами и российскими правовыми актами.

Представляют также интерес положения Модельного УПК для государств-участников СНГ, утвержденного Межпарламентской Ассамблеей посударств-участников СНГ в 1996 г.13 •

В Модельном УПК взятию лица под стражу для выдачи посвящены статьи 587-589, в принципе соответствующие международным обязательствам РФ.

Так, ст. 587 Кодекса предусматривает, что до принятия решения о выдаче, принимаются меры к взятию под стражу лица, выдача которого требуется. При этом взятое под страху лицо имеет право представить перед судьей для утверждения, изменения или отмены избранной в отношении него меры пресечения.

Устанавливается Кодексом (ст. 588) и возможность взятия под стражу или задержание до получения требования о выдаче - по ходатайству. 
Статья 589 Кодекса регулирует вопросы освобождения задержанньх или взятых под стражу согласно положениям статей 587 и 588 .

Любопытно, что в проекте УПК РФ, обсуждаемом в настоящее время в Федеральном Собрании РФ, заключение под стражу для вьцачи регламентировано лишь одной статьей (519), которая, в частности, гласит:

"(1) При получении от компетентного учреждения иностранного государства надлежащее оформленного требования и при наличии законных оснований для выдачи лица, оно может быть задержано и к нему применяется мера пресечения в виде заключения под стражу в порядке, установленном статъей 101 настоящего Кодекса.

(2) О заключении под страху лица немедленно уведомляется учреждение иностранного государства, направившее просьбу о выдаче, с предложением о времени и месте выдачи.

(3) Если в течение тридцати суток выдача не состоялась, лицо, содержащееся под стражей, подлежит освобождению по постановлению прокурора. Повторное заключение под стражу допускается только после рассмотрения нового требования о выдаче в соответствии с частъю первой настоящей статъи".

Как видим, проект УПК не учитывает многих положений мехдународных договоров РФ (о реквизитах поручения, о ходатайстве Как возможном основании для ареста, о задержании подозреваемых и т.д.) и правил Модельного УПК.

В связи с вышеизложенным представляется необходимым:

1. Дополнить статью 96 УПК РСФСР частью седьмой следующего содержания:

“Задержанному или арестованному иностранному грахданину разъясняется его право связаться с представителем государства его гражданства и право посещения его этим представителем".

2. Дополнить УПК Статьей 96.3 следуюшего содержания:

"Статья 96.3. Заключение под стражу в целях обеспечения выдачи

По получении просьбы о выдаче Генеральная прокуратура РФ немедленно принимает меры к заключению под страху лица, выдача которого требуется, за исключением тех случаев, когда согласно международному договору выдача не допускается.

О всяком случае закпючения под стражу иностранного гражданина немедленно уведомляют дипломатическое и консульское представительства соответствующего государства и Министерство иностранньх дел РФ.

Генеральная прокуратура РФ должна затребовать дополнительные сведения, если просьба о выдаче не содержит необходи- 
мbх данньх. Если учреждение юстиции иностранного государства не представит в течение 30 дней дополнительных сведений, лицо, взятое под стражу, должно быть освобождено.

К просьбе о выдаче для осуществления уголовного преследования, должна быть также приложена копия постановления о взятии под стражу или ордера на арест, выданного компетентным органом запрашиваюшего государства.

К просьбе о выдаче для приведения приговора в исполнение должны быть приложены также:

копия приговора по уголовному делу, вступившего в законную силу;

справка об отбытой части срока наказания.

Лицо, взятое под страху в соответствии с положениями части первой настоящей статьи, имеет право предстать перед судьей для утверждения, изменения или отмены избранной в отношении него меры пресечения.

Лицо, взятое под стражу согласно части первой настоящей статьи, долхно быть освобождено, если в течение 30 дней со дня взятия под стражу от запрашивающего учреждения юстиции не поступят просьба о выдаче и необходимые документы".

3. Дополнить УПК статьей 96.4 следующего содержания:

"Статья 96.4. Взятие под стражу до получения просьбы о выдаче

В случаях, не терпящих отлагательства, лицо, выдача которого требуется, может быть взято под стражу и до получения требования о выдаче - по ходатайству иностранного государства.

Ходатайство должно быть передано по почте, телеграфу, телексу или телефаксу.

В ходатайстве долхны содерхаться сведения о лице, выдача которого требуется, о его местожительстве и местопребывании, если об энм известно; краткое описание фактических обстоятельств дела; сведения о наличии постановления о взятии под стражу или ордера на арест Либо вступившего в законную силу приговора и указание на то, то просьба о выдаче будет выслана незамедлительно.

В течение 5 дней после получения ходатайства компетентный орган долхен сообщить запрашивающему учрехдению юстиции о результатах его рассмотрения.

Лицо. взятое под стражу в соответствии с положениями части первой настоящей статьи, имеет право предстать перед судьей для утверждения, изменения или отмены избранной в отношении него меры пресечения.

Лищо, взятое под страху по ходатайству, долхно быть освобождено, если в течение одного месяца с момента взятия под 
стражу от иностранного государства не поступит просьба о выдаче".

4. Дополнить статью 122 УПК частями третьей и четвертой следуюшего содержания:

"Лицо может быть задержано и без ходатайства, предусмотренного статьей 96.4 настоящего Кодекса, если имеются предусмотренные законом основания подозревать, что оно совершило на территории другого государства преступление, влекущее выдачу. О всяком случае задержания иностранного гражданина немедленно уведомляют дипломатическое и консульское представительства соответствующего государства и Министерство иностранньх дел РФ.

Лищо, взятое под стражу в соответствии с положениями части первой настоящей статьи, имеет право предстать перед судьей для утверждения, изменения или отмены избранной в отношении него меры пресечения.

Часть третью статьи 122 УПК считать частью пятой.

5. Дополнить статью 97 УПК частью второй следуюшего содержания:

“Содержание под стражей лица, в отношении которого такая мера пресечения избрана в порядке оказания правовой помощи, не может продолхаться больше тридцати дней, если иной срок не предусмотрен международными договорами Российской Федерации".

6. Включить предложенные нормы в новый УПК РФ.

1. Бюллетень международньх договоров. 1995. № 2.

2. Вестник Высшего арбитражного суда РФ. 1997. № 8.

3. Сборник международньг договоров СССР. Вып. XLIII, 1989. C. 70-85.

4. Сборник мехдународньх договоров Российской Федерации по оказанию правовой помощи. М., 1996.

5. Там же.

6. Там же.

7. Бюллетень международных договоров. 1995. № 6.

8. С3. 1995. № 21. Ст. 1932.

9. Дитломатический вестник. 1995. № 7.

10. Бюллетень международньхх договоров. 1995. № 5.

11. C3. 1995. № 20

12. Бюллетень Генератьной прокуратуры РФ. 1993. № 4.

13. Информационньй бюллетень. 1996. № 10. Приложение 